\title{
Studi Fenomenologi Tentang Pengalaman Pasien Hipertensi Terhadap Perawatan Dirinya Di Wilayah Kerja Puskesmas Andalas Padang Tahun 2017
}

\author{
Elvi Oktarina ${ }^{\text {a }}$, Hayatunnupus Haqiqi ${ }^{b}$, Esi Afrianti ${ }^{a}$ \\ aBagian Keperawatan Medikal Bedah - Keperawatan Gawat Darurat Fakultas Keperawatan \\ Universitas Andalas, 25163, Indonesia \\ ${ }^{b}$ Fakultas Keperawatan Limau Manis, Padang, 25163, Indonesia \\ e-mail korespondensi: oktarina.vye@ gmail.com \\ esi_afriyanti@yahoo.com
}

\begin{abstract}
Uncontrolled hypertension causes heart attacks, Cardiomegali, Heart Failure, Stroke, Kidney Failure, Blindness, and Cognitive Impairment. It requires proper strategy to maintain blood pressure in patients with hypertension called self management which consist of medication compliance, normal weight maintanance, low sodium consumption, physical activity, alcohol restriction and smoking cessation.. This research aimed to explore a deep understanding about the experience of Hypertension patients in carrying out self management. This research used qualitative method with descriptive phenomenology. Four people are selected by puposive sampling technique. Technique of data collection in this research with in-depth interviews. The data finding of this research were analyzed using Collaizi's method. The finding of data analyze is found eight theme: (1) the response to the disease suffered high blood pressure (2) first experience of hypertension (3) controlling (4) to cope with drug (5) maintain the health of the body (6) dietary changes (7) not smoking and drinking alcohol(8) family support. In this research, This research sugested the healthcare provider to contribute to improve information and knowledge of hypertension patients related to self management such as light exercise activities at home, salt consumption controlling, dietary recommendation and dietary restriction.
\end{abstract}

Keywords: Hypertension Patient, Self care, Fenomenology, Kualitatif

\begin{abstract}
Abstrak
Hipertensi tidak terkontrol menyebabkan serangan jantung, pembesaran jantung, gagal jantung, stroke, gagal ginjal, kebutaan, dan gangguan kognitif. Mengatasi kondisi tersebut idealnya dilakukan pengontrolan tekanan darah pada pasien hipertensi dengan melakukan perawatan diri yang terdiri dari kepatuhan terhadap pengobatan, penurunan berat badan atau pemeliharaan berat badan ideal, diet rendah garam, olahraga, pembatasan konsumsi alkohol dan berhenti merokok. Penelitian ini bertujuan untuk mengeksplorasi pemahaman yang mendalam tentang pengalaman pasien hipertensi dalam melaksanakan perawatan dirinya. Metode yang digunakan adalah metode kualitatif dengan pendekatan fenomenologi deskriptif. Pemilihan partisipan diambil dengan cara purposive sampling sebanyak empat orang. Pengumpulan data dilakukan dengan wawancara mendalam. Data yang diperoleh dianalisis dengan metode Collaizi's. Dari hasil analisa data ditemukan delapan tema utama yaitu : (1) respon terhadap penyakit tekanan darah tinggi yang diderita (2) pengalam pertama hipertensi (3) melakukan kontrol (4) mengatasi dengan obat (5) menjaga kesehatan tubuh (6) perubahan pola makan (7) tidak merokok dan minum alkohol (8) dukungan keluarga. Dengan adanya penelitian ini, diharapkan adanya kontribusi pelayanan kesehatan untuk meningkatkan informasi dan pengetahuan pasien hipertensi terkait perawatan diri seperti olahraga ringan yang dapat dilakukan dirumah, pengendalian mengkonsumsi garam, makanan yang harus dikonsumsi dan makanan yang tidak boleh di konsumsi pada pasien dengan hipertensi.
\end{abstract}

Kata kunci: Perawatan Diri, Pasien Hipertensi, fenomenologi, Kualitatif

\section{PENDAHULUAN}

Hipertensi dikenal dengan "the sillent killer" dimana Penderita tidak mengetahui bahwa dirinya menderita hipertensi. Kondisi ini dikarenakan gejala yang tidak dirasakan sampai penderita diketahui tekanan darah terlalu tinggi dan mungkin telah terjadi komplikasi yang dapat mengakibatkan kematian (Noviyanti, 2015). Mortalitas terjadi lebih cepat apabila hipertensi tidak terkontrol dan telah 
menimbulkan komplikasi ke beberapa organ vital. Sebab kematian yang sering terjadi adalah penyakit jantung dengan atau tanpa disertai stroke dan gagal ginjal (Hoeymans et al, 2013).

Komplikasi yang terjadi pada hipertensi ringan dan sedang mengenai mata, ginjal, jantung dan otak. Pada mata berupa perdarahan retina, gangguan penglihatan sampai dengan kebutaan. Gagal jantung merupakan kelainan yang sering ditemukan pada hipertensi berat selain kelainan koroner dan miokard. Pada otak sering terjadi stroke dimana terjadi perdarahan yang disebabkan oleh pecahnya mikroaneurisma yang dapat mengakibakan kematian. Kelainan lain yang dapat terjadi adalah proses tromboemboli dan serangan iskemia otak sementara. Gagal ginjal sering dijumpai sebagai komplikasi hipertensi yang lama dan pada proses akut seperti pada hipertensi maligna (Susalit E, 2010)

Menurut Maria (2011) berbagai tindakan telah dilakukan untuk pencegahan dan pengendalian hipertensi, tetapi kasus hipertensi tetap meningkat. Jika penyakit hipertensi tidak terkontrol, serta pengendalian dan pencegahan faktor resiko tidak di cegah maka masalah ini akan meningkat secara signifikan pada tahun 2020. Penyakit hipertensi tidak boleh diabaikan karena penderita hipertensi semakin meningkat. Dan dari jumlah total penderita hipertensi baru sekitar 50 persen yang terdeteksi dan hanya setengah yang berobat teratur, begitu juga di Indonesia (Suiraoka, 2012)

Menurut data WHO (World Health Organization) tahun 2013 menyatakan bahwa tahun 2012 penyakit jantung membunuh 17,5 juta orang atau setara dengan setiap 3 dari 10 kematian. Dari 17,5 juta orang $45 \%$ kematian akibat hipertensi. Prevalensi hipertensi pada tahun 2013 dengan jumlah kasus 972 juta orang atau 26,4\% mengidap hipertensi. Angka ini kemungkinan akan meningkat menjadi 29,2\% di tahun 2030. Dari 972 juta pengidap hipertensi, 333 juta berada di negara maju dan 639 sisanya berada di negara sedang berkembang. Sedangkan menurut American Heart Association (AHA) statiscal update tahun 2017 menyatakan bahwa prevelensi hipertensi pada orang dewasa di Amerika berusia $\geq$ 20 tahun diperkirakan 34,0\% yang setara dengan 85,7 juta orang dewasa pada tahun 2011 sampai 2014 (Benyamin, 2017)

Berdasarkan data Riskesdas tahun 2013, prevelensi hipertensi di Indonesia adalah sebesar 25,8 \%. Sedangkan jika dibandingkan pada tahun 2007 prevelensi hipetensi cenderung turun dari $31,7 \%$ menjadi 25,8\% pada tahun 2013. Penurunan ini diperkirakan terjadi karena beberapa faktor seperti perbedaan alat ukur yang digunakan pada tahun 2007 tidak diproduksi lagi pada tahun 2013, kesadaran masyarakat tentang bahaya penyakit hipetensi dan adanya kesadaran masyarakat untuk memeriksa kesehatan ke tenaga kesehatan. Meskipun prevalensi hipertensi dari tahun 2007 dengan prevalensi $31,7 \%$ ke tahun 2013 dengan $25,8 \%$ mengalami penurunan tetapi prevalensi hipertensi tahun 2013 di Indonesia masih tinggi. Berdasarkan data Riskesdas tahun 2013, prevalensi hipertensi di Sumatera Barat menduduki peringkat ke empat dengan persentase 22,6 persen (Pusat Data Dan Informasi Kementerian Kesehatan RI, 2013).

Berdasarkan wawancara yang dilakukan enam orang pasien hipertensi yang berkunjung ke Puskesmas Andalas Padang. Didapatkan hasil empat orang perempuan dan dua orang laki-laki dengan usia ratarata diatas 40 tahun. Empat orang pasien cenderung tidak melakukan kontrol secara teratur dengan alasan tidak ada waktu karena bekerja, tidak ada yang mengantarkan pergi berobat dan bosan untuk berobat serta tidak teratur minum obat karena lupa. Lima orang cenderung tidak mematuhi aturan diet hipertensi dengan alasan susah mengatur makanan secara terpisah dan merasa bosan dengan diet rendah garam. Tiga orang pasien jarang melakukan olahraga dengan alasan 
tidak punya waktu dan hanya berjalanjalan sekitar kurang dari 10 menit sekitar rumah, dua orang pasien laki-laki tetap merokok karena susah menghentikan kebiasaan rokok dan satu orang partisipan terkadang mengkonsumsi alkohol apabila diajak oleh teman.

Menurut Gohar et al (2008) untuk pemantauan tekanan darah pada pasien hipertensi diperlukan strategi dalam pengontrolan tekanan darah. Pada pasien hipertensi untuk pengontrolan tekanan darah diperlukan kemampuan pasien dalam merawat dirinya

Menurut Bauman (2012) perawatan diri ini merupakan kemampuan individu, keluarga dan masyarakat untuk mempromosikan kesehatan, mencegah penyakit, dan memelihara kesehatan untuk mengatasi penyakit dan kecacatan tanpa dukungan dari pelayanan kesehatan. Berdasarkan penelitian yang telah dilakukan oleh Prihandana (2012) menemukan enam tema tentang kepatuhan perawatan mandiri hipertensi yaitu pengalaman kepatuhan kontrol, pengalaman menangani gejala dan komplikasi, pengalaman kepatuhan minum obat, pengalaman kepatuhan mengelola, kurang patuh olahraga dan kendala untuk patuh. Menurut penelitian Shima (2014) menemukan adanya beberapa tema dalam perilaku pasien dalam perawatan hipertensi diantaranya hambatan dan pendukung dari ketidapatuhan perawatan hipertensi dalam mengkonsumsi obat antihipertensi, hambatan dan pendukung dari ketidakpatuhan terhadap perawatan hipertensi dalam aktivitas fisik dan diet, dan masalah dengan profesional perawatan kesehatan dan sistem perawatan kesehatan. Melihat berbagai fenomena terkait perawatan diri pada pasien hipertensi, maka peneliti tertarik untuk mengeksplorasi lebih dalam bagaimana pengalaman perawatan diri pada pasien hipertensi. Berdasarkan hal tersebut, sehingga peneliti tertarik melakukan penelitian tentang pengalaman pasien hipertensi terhadap perawatan diri dalam usaha mengendalikan tekanan darahnya

\section{METODE}

Penelitian ini menggunakan desain penelitian kualitatif fenomenologi. Pemilihan partisipan dalam penelitian ini menggunakan teknik purposive dengan kriteria inklusi : Partisipan yang mengalami penyakit hipertensi primer, Kontrol ke Puskesmas Andalas Padang, Berusia 45-54 tahun, Dapat mendengar, berbicara dengan jelas dan masih dapat mengerti pertanyaan yang diajukan, Berorientasi dengan baik, Pernah mendapatkan edukasi tentang hipertensi. Sampel berjumlah 4 orang setelah tercapai kejenuhan (saturated) pada data yang diperlukan atau tidak dapat informasi baru yang dibutuhkan (Patton (2002 dalam Afiyanti\& Rachmawati 2014). Prosedur pengumpulan data menggunakan metode wawancara mendalam (indepth interview) . Jenis wawancara yang akan dilakukan adalah wawancara semi terstruktur dengan pertanyaan terbuka menggunakan pedoman wawancara. Peneliti menjadi alat pengumpul data dan mendengarkan deskripsi yang diberikan oleh partisipan selama wawancara berlangsung yang kemudian dipelajari, ditranskipkan, dan ditelaah berulang-ulang.

\section{HASIL}

Berdasarakan kata kunci yang dianalisis melalui transkip verbatim didapatkan 6 tema yaitu : (1) respon terhadap penyakit (2) pengalaman pertama hipertensi (3) melakukan kontrol (4) mengatasi dengan obat (5) menjaga kesehatan tubuh (6) perubahan pola makan (7) tidak merokok dan minum alkohol (8) dukungan keluarga

\section{PEMBAHASAN}

\section{Respon \\ Tekanan Darah Tinggi}

Terhadap Penyakit

Berdasarkan hasil penelitian yang telah dilakukan bahwa partisipan mengetahui dengan hipertensi, mengalami respon fisik 
“...gejalanya kayak kepala saya sangat sakit sekali, pusing, kuduk ni terasa berat badan terasa gak enak.."(P2)

dan respon psikologis akibat penyakit tekanan darah yang dideritanya

“..Pas waktu tu heran awak ndak biaso tensi awak sagituh do kan...” P3

Hasil penelitian didapatkan patisipan mengetahui tentang hipertensi dengan baik, dibuktikan dengan partisipan dapat menyebutkan dan mengenali gejala yang dirasakan apabila mengalami hipertensi. Peningkatan tekanan darah dikeluhkan secara berbeda oleh partisipan. Berbagai keluhan karena gangguan sirkulasi muncul sebagai rasa pusing, tengkuk terasa berat, kepala sakit. Menurut hasil penelitian Windarti (2008) menyatakan bahwa ada gejala yang dirasakan oleh sebagian orang dengan hipertensi. Gejala-gejala tersebut bervariasi, antara lain sakit kepala, pusing, migren, perdarahan dihidung, sukar tidur, telinga berdenging, tengkuk terasa berat, berdebar dan sering kencing dimalam hari

Respon psikologis partisipan muncul sebagai respon kehilangan. Pada penelitian ini partisipan menyampaikan perasaan tentang penyakit yang dialaminya. Semua partisipan tidak percaya dengan penyakit yang dialaminya saat ini, perasaan takut, dan cemas akan dampak dari penyakit tekanan darah tinggi seperti stroke dan penyakit jantung. Menurut Yupan, et al (2015) menyatakan bahwa pasien hipertensi memiliki resiko kecemasan yang paling tinggi dibandingkan pada pasien yang tidak memiliki tekanan darah tinggi.

\section{Pengalaman Pertama Hipertensi}

Hasil penelitian mendapatkan bahwa partisipan mengatakan gambaran ketika terjadinya gejala yang dirasakan partisipan.

“..sebelumnya badan ibuk udah gak enak, lagi duduk bumi ini terasa berputar, pokoknya tiba-tiba aja.." (P1)
Dengan situasi tersebut partisipan berusaha untuk mengatasi gejala yang memperburuk keadaan partisipan. Setiap partisipan melakukan berbagai cara untuk menghilangkan gejala yang dirasakan

“..iya saya tahan sakitnya, bawa tidurtiduran, tapi pas sore itu gak bisa lagi di tahan.."(P2)

“..pas sakik tu langsuang awak minum ubek kadai yaitu procold se nyo.. "(P3)

Selain itu partisipan mencari pertolongan pertama pelayanan kesehatan atau ke apotik setelah tidak bisa mengurangi gejala.

“..awalnya ibuk ke bidan dulu, kan ibuk kena"nya magrib itu ibuk ke bidan, dan di kasih obat sama bidan, tu ibu minum daun pokat, setelah dua hari sakit baru ibuk ke puskesmas.."(Pl)

National Heart, Lung and Blood Institute (2013) menyatakan dalam artikelnya bahwa penderita darah tinggi harus terus menerus mendapatkan perawatan medis dan mengikuti anjuran dari pertugas kesehatan. Perawatan darah tinggi memang harus tetap dilakukan meskipun kondisi pasien sedang sehat, sehingga tekanan darah tetap bisa di kontrol

\section{Melakukan Kontrol}

Melakukan kontrol merupakah hal yang dilakukan partisipan untuk memantau tekanan darah partisipan. Pada hal ini teridentifikasi partisipan kontrol karena ada olahraga yang selalu diadakan oleh pihak puskesmas setiap hari senin dan kamis sehingga membuat partisipan ingin ke puskesmas untuk melakukan kontrol.

“..karena ada olahragakan hari selasa sekalian bisa cek darah (tekanan darah) tiap pagi dan kesehatan tu makonyo 
(sehingga)ibuk semangat ka puskesmas.." (P2)

Selain itu alasan untuk kontrol yaitu karena partisipan merasa cocok dengan obat puskesmas, dan telah adanya jaminan kesehatan yang membuat partisipan ingin untuk melakukan kontrol.

“.lebih cocok kayaknya di
puskesmas.."(P2)

“...lagian ibuk ada kartu askes dan juga puskesmasnya dekat dari rumah ibu.." (P4)

Hal tersebut sesuai dengan tujuan dasar JKN yaitu memberikan perlindungan keuangan kepada peserta agar mereka tidak mengalami kesulitan biaya ketika sakit.

Menurut American Heart Association (2014) yang menyebutkan bahwa penderita hipertensi dengan tekanan darah sistolik $140-159 \mathrm{mmHg}$ dan diastolik $90 \quad-99$ $\mathrm{mmHg}$ perlu melakukan kontrol tekanan darah 3 bulan sekali, sedangkan penderita hipertensi dengan tekanan darah sistolik> $160 \mathrm{mmHg}$ dan diastol $>100 \mathrm{mmHg}$ perlu melakukan kontrol tekanan darah $2 \quad-4$ minggu sekali.

"...iya dalam satu bulan sekali saya pergi kontrol ke Puskesmas.” (P2)

Dalam hasil penelitia ini juga didapatkan bahwa partisipan tidak kontrol rutin pada awal terkena hipertensi sampai sekarang. Hal tersebut terjadi karena partisipan tidak merasakan gejala yang mengganggu aktivitasnya.

“...indak lo do sakali sabulan, kalau misalnyo ubek tensi masih ado ndak pai awak do, kalau ala habis ubeknyo baru awak pai lai.."(P2)

Hal tersebut sesuai dengan yang disampaikan oleh Riaz (2012), bahwa pasien pertama kali mengalami hipertensi berada dalam tahap asimptomatik.
Mengatasi dengan obat

Berdasarkan hasil penelitian semua partisipan menjelaskan tentang pegobatan. WHO (2012) bertujuan untuk mencapai penggunaan obat-obatan yang rasional dengan mengacu pada penggunaan obatobatan yang bertanggung jawab yang berarti pasien menerima obat-obatan yang tepat pada waktu, menggunakan obat yang tepat dan menimbulkan manfaat bagi pasien, sehingga penting memiliki pengatahuan dan kesadaran tentang pengobatan. Rakha (2015) penggunaan obat antihipertensi pada pasien hipertensi yang meliputi ketepatan obat, ketepatan dosis, dan kepatuhan pasien dalam meminum obat. Sehingga dalam penelitian partisipan telah mengetahui tentang penggunaan obat dan dosis obat yang diminum.

“...karena obatnya satu kali sehari minumnya setiap malam sebelum tidur dan minumnya malam hari mau tidur.." (P2)

\section{Menjaga Kesehatan Tubuh}

Pada penelitian ini terdapat perubahan berat badan ketika sakit. Partisipan menyatakan terjadi perubahan berat badan baik itu terjadi penurunan maupun kenaikan berat badan. Pada partisipan mengalami kenaikan berat badan partisipan berupa untuk melakukan pemeliharaan berat badan karena partisipan takut akan obesitas.

"...ooohhhh iyooo, kalau itu iyo tu ma diak raso-raso katurun barek badan jauh kini turun barek badan ibu yg ibu rasoan, ndak ibu se marasoan do urang marasoan lo tu, sabalum sakik agak barisi badan ibu tu kini samanjak sakik ko agak kurang barek badan ibu rasonyo..."(P3)

(oohh iya, kalau itu iya dek rasa-rasa turun berat badan jauh kini turun berat badan bu yang ibu rasakan, tidak ibu merasakan orang lain juga merasakan, sebelum sakit sedikit berisi badan ibu itu 
kini semejak sakit sedikit kurang beratbadan ibu rasanya) (P3)

Menurut Suraika (2012) pasien hipertensi dengan keadaan obesitas memiliki curah jantung dan volume darah yang lebih tinggi dibandingkan dengan pasien hipertensi yang tidak gemuk. Sehingga perlu bagi pasien hipertensi menjaga berat badan. Selain itu aktivitas fisik yang dilakukan partisipan adalah melakukan senam diadakan di puskesmas,

“..kalau olahrga bapak paling bapak olahraganya ya.. terkadang hari minggu pergi ke gor jalan-jalan atau hari selasa bapak pergi ke puskesmas olahraga karena tiap hari selasa olahraga di puskesmaskan jadi bapak ikut.." (P2)

Namun tidak semua partisipan melakukannya.

“..indak sampai satangah jam do bajalan do, tampek karajoibuk kan duo tu bajalan ibuk ka situ.. P3

(tidak sampai setengah jam bajalan, ke tempat kerja ibu cumaitu aja berjalan kasitu) (P3)

Menurut Astrand (2013) olahraga dalam arti sempit adalah latihan gerak badan untuk menguatkan atau menyehatkan badan. Secara umum olahraga tidaklah sekedar bermanfaat untuk membina kesegaran jasmani saja, akan tetapi dapat pula mengobati beberapa jenis penyakit, diantaranya ialah penyakit jantung, diabetes mellitus dan hipertensi.

“...kalau giat awak senam indak sakik jantung do, kata orang kan kalau hipertensi ini lama-lama bisa jantung kan.. "P1

(kalau rajin kita senam tidak sakit jantung, kata orang kan kalau hipertensi ini lama-lama bisa jantungkan ) (P1)

Pada penelitian ini sebagian partisipan mengikuti grup Prolanis (Program Penanggukangan Penyakit Kronis ) yang diadakan di Puskesmas yang merupakan salah satu program pemerintah yang merupakan bentuk latihan jasmani aerobik. Menurut penelitian yang dilakukan Deiby (2016) menyatakan bahwa terdapat perubahan rata-rata tekanan darah sebelum dan sesudah latihan senam baik pada latiham dua kali seminggu atau tiga kali seminggu. Hal ini sangat penting untuk menekankan kepada pasien bahwa kunci sukses dalam olahraga adalah konsistensi waktu.

Perubahan Pola Makan

Perubahan pola makan yang dilakukan partisipan ketika sebelum sakit dan sesudah mengalami hipertensi. Pola makan partisipan saat ini sangat dibatasi sekali mengkonsumsi lemak, hal tersebut dilakukan partisipan untuk menurunkan tekanan darah. Sehingga partisipan cenderung memakan makanan yang tinggi serat dan vitamin.

“..kalau daging sih jarang, apa lagi jeroan jarang sekali karenaitu sangat bapak kurangi dari dulu, takut makanmakanan tinggi lemak..”. (P2)

“..goreng, sayuran kayak bayam, kangkung, lobak, kini banyak se (aja) makan sayur lai (lagi) dari pado makanmakan tinggi kolesterol.." (P4)

"...tidak terasa garam sih, makanan istri bapak hambar aja bagi orang lain, tapi bagi bapak biasa aja karena udah terbiasa..."(P2)

Menurut Kusuma (2009) kandungan kolesterol dalam daging kambing dan sapi ditakutkan menyebabkan intake kolesterol tubuh yang berlebihan. Jeroan kambing dan sapi mengandung lemak jenuh tingg. Pada penelitian Lu Wang et al (2012) membuktikan bahwa asupan kalium yang tinggi dapat menurunkan tekanan darah. Sebaliknya, kenaikan kadar natrium dapat merangsang sekresi rennin dan mengakibatkan penyempitan pembuluh darah perifer yang berdampak pada 
meningkatnya tekanan darah. Selain itu pada penelitian ini sebagian besar partisipan dalam penelitian ini melakukan diit rendah sodium untuk mencegah kenaikan tekanan darah seperti mengurangi konsumsi garam. Penelitian yang dilakukan Stephen (2017) menyatakan bahwa asupan natrium yang berkurang dan diet DASH dapat menurunkan tekanan darah untuk mengurangi resiko komplikasi (Barak, F., Falahi, E., \& Kesthteli, H. (2014).

Tidak Merokok dan Alkohol

Dalam penelitian didapatkan tidak ada partisipan yang merokok secara aktif dan meminum alkohol. Karena bagi partisipan meminum alkohol adalah sesuatu yang merugikan dan tidak bermanfaat.

"...sudah lama tidak merokok,, udah hampir 20 tahun lebih...”(P2)

Menurut Dermawan (2012) nikotin yang ada didalam rokok dari tembakau menyebabkan pembuluh darah mengerut (konstriksi) dan denyut jantung menjadi lebih cepat yang secara sementara akan menaikkan tekanna darah. Sedangkan alkohol. Menurtu penelitian yang dilakukan Kenneth (2015) menyatakan bahwa konsumli alkohol tiga atau lebih minuman perhari jelas meningkatkan tekanan darah, salah satu faktor resiko kardiovaskuler.

\section{Dukungan Keluarga}

Pada penelitian ini dukungan keluarga adalah terdapat dari suami, istri, anak dan menantu. Dukungan keluarga tergambarkan adalah dukungan sosial. Walaupun partisipan tidak semua jenis dukungan mereka dapat. Dukungan finansial, mental yang didapatkan sangat berarti bagi partisipan.

“..Terkadang istri yang mengingatkan selalu minum obatnya karena nanti takut tensinya naik lagikan.." (P2)
Penelitian yang silakukan oleh Kusumaning (2013) membuktikan bahwa ada hubungan antara dukungan sosial keluarga dan hipertensi. Jadi dukungan sosial dari keluarga dirasakan sebagai penyemangat untuk selalu melakukan pengobatan, perubahan dalam mengkonsumsi makanan.

\section{Kesimpulan}

Respon partisipan terhadap
penyakit hipertensi yang diderita
tergambar sebagai respon fisik dan
psikologis. Dalam hal ini partisipan dapat
mengidentifikasi respon tersebut dan
beradaptasi dengan kondisi fisiknya.

Pengalaman pertama hipertensi berdasarkan hasil peneliitan didapatkan bahwa partisipan ketika mengalami gejala yang dirasakan maka partisipan berusaha untuk menghilangkan gejala tersebut.

Melakukan kontrol partisipan didapatkan bahwa partisipan pada awal terkena hipertensi langsung pergi kontrol ke puskesmas. Namun partisipan tidak melakukan kontrol secara rutin, partisipan melakukan kontrol setelah mengeluhkan adanya gejala.

Partisipan menjalani pengobatan sesuai dengan anjuran yang telah ditetapkan oleh tenaga kesehaan tetapi partisipan belum teratur menjalani pengobatan karena berbagai alasan yang dikemukan oleh partisipan.

Partisipan mengetahui pentingnya olahraga yang dilakukan dan menjalani olahraga untuk menjaga kesehatan dengan tujuan penyakit yang dialaminya tidak menyebabkan komplikasi yang serius.

Perubahan pola makan pada partisipan terjadi ketika partisipan telah mengalami hipertensi sehingga pada saat inip partisipan mengkonsumsi makanan rendah lemak dan tinggi protein, serat dan vitamin 
Pembatasan konsumsi sodium merupakan tindakan untuk mencegah kenaikan tekanan darah. Pembatasan garam yang dilakukan partisipan dengan mengurangi jumlah atau takaran garam harian partispan

Tidak ada merokok dan minum alkohol merupakan hal yang dianggap tidak pantas dan tidak harus dilakukan oleh partisipan karena dapat merugikan bagi partisipan

Dukungan keluarga yang didapatkan partisipan berupa dukungan mental, informasi, instrumental dan finansial. Dukungan dari keluarga ini telah diperoleh oleh partisipan sehingga bersemangat melakukan perawatan hipertensi dirumah

\section{Saran}

Bagi Pelayanan Kesehatan

Diharapkan peningkatan pelayanan yang lebih baik terutama pendidikan kesehatan tentang hipertensi seperti dalam pemberian promosi kesehatan atau group discussion. Dengan demikian akan manambah wawasan pasien dalam melakukan perawatan diri hipertensi sehingga dapat mengaplikasinya dalam kehidupan seharihari pasien karena selain pengobatan juga penting tentang pola hidup sehat seperti melakukan olahraga teratur, mengkonsumsi sayur dan buah dan mengurangi makanan yang berlemak yang harus dilakukan oleh pasien dengan penyakit hipertensi.

\section{Bagi Institusi Pendidikan Keperawatan}

Meningkatkan pengetahuan peserta didik dalam melakukan perawatan diri pada pasien hipertensi. Selain itu hal ini juga dapat menigkatkan hal-hal yang berkaitan dan dianggap penting untuk pasien hipertensi dalam menjaga tekanan darahnya.

Bagi peneliti selanjutnya

Peneliti menyarankan kepada peneliti selanjurnya untuk diadakan penelitian yang lebih mendalam tentang pengalaman pasien hipertensi terhadap perawatan dirinya pada partisipan dengan hipertensi sekunder dan dengan rentang umur yang berbeda seperti pada lansia. Penelitian ini juga dapat dilakukan dengan metode lainnya untuk mempengaruhi faktor lain yang mempengaruhi perawatan diri pada pasien hipertensi.

\section{Referensi}

Afiyanti, Y., \& Rachmawati. (2014). Metodologi penelitian kualitatif dalam riset keperawatan. Jakarta : Rajawali Pers

Benyamin, E., J. (2017). AHA statistical update heart disease and stroke statistic-2017 update : A report from the american heart association. American Heart Association, Inc.

Barak, F., Falahi, E., \& Kesthteli, H. (2014). Adherence to the dietary approacches to stop hipertension (DASH) diet in relation to obesity among iranian female nurses. Public Helath Nutrition: 18 (4), 705- 712

Bauman, L,C, Dang, T, N. (2012). Helping patient with chronic condition overcome barriers to self-care. The Nurse Practitioner, Volume 37, No: 3

Breaux T, L. Kethleen, C., Erica, R., \& Elizabeth H. (2012). Relationship of blood pressure self-monitoring, medication adherence, self-efficacy, stage of change, and blood pressure control among municapal workers with hypertension. Workplace health daf 60 (7)

Chowdury, T., Okumura, T., Afzal, Raheen, A., Nahid, \& Makoto. (2016). Hypertension and lifetime risk of stroke. Journal of hypertension, Vol : 34-issue 1: 116122 
NERS: Jurnal Keperawatan, Volume 14, No. 1, Maret 2018, (Hal. 1-10)

Dermawan. (2012). Waspadai gejala penyakit mematikan. Jakarta Selatan : PT Suka Buku

Deiby, O., Herlina, W, \& Polii, H, (2016). Pengaruh senam prolanis terhadap penyandang hipertensi. Jurnal ebiomedik. Volume 4 No :1

Findlow, J., Rachel, B., \& Seymour. (2011). Prevalence rates of hypertension self-care activities among african americans, 103(6): $503-512$

Findlow,W., Racherl, B., Seymour, Larissa, R, \& Huber,B. (2012). The association between self-efficacy and hypertension self-care activities among african american adults, 37(01): 15-24

Gohar, F,. Greenfield, M., Beevers, D.G., Lip, G.YH., \& Jolly, K. (2008) Self care and adherence to medication: A survey in the hypetension outpatient clinic. BMC Complementary and Alternative Medicine, 8 (04) : 1-9

Hoeymans, N., Smith, Verkleij H., \& Kromhout D. (2013). Cardiovascular Risk Factors in Netherlands. Eur Heart. Volume 7 :520

Kenneth J, \& Mukamal. (2015). The effect of smoking and drinking on cardiovaskuler disease and risk factor. British Medical Journal 319:1523-1528

Maria, Z. (2011). Hypertension-a public health problem. Journal of Universidase de Fortalea Brasil

National Heart Lung anf Blodd Institute (2013). What is blood pressure, Januari, $\quad 10, \quad 2018$. http://www.nhlbi.nih.goc/health/dci/ disease.Hbp/HBP-what/s.html

Noviyanti, (2015). Kenali, cegah dan obat Hipertensi. Yogyakarta : Notebook
Prihandana, S. (2012). Sudy fenomenologi: Pengalaman kepatuhan perawatan mandiri pasien hipertensi di poliklinik RSI Siti Hajar kota Tegal. Tesis UI

Pusat Data dan Informasi Kementrian Kesehatan RI Hipertensi 2013

Raynna, C. (2015). Self-care comparison of hypertensive patients in primary and secondary health care services 28(6):580-6.

Rakha. (2015). Evaluasi penggunaan obat antihipertensi pada pasien hipertensi rawat jalan di puskesmas sempaja samarinda. Jurnal Sains dan Kesehatan. Vol 1. No 2. 82 ISSN: 2303-0267, e-ISSN: 2407-6082

Riaz, K. (2014). Hypertensive Heart Disease. The heard medscape

Suiraoka. (2012). Penyakit degeneratif : Mengenal, mencegah dan mengurangi faktro resiko 9 penyakit degeneratif. Yogyakarta: Nuha Medika

Susalit E, Kapojos J., \& Lubis R. (2010). Hipertensi Primer Dalam Buku Ajar Ilmu Penyakit Dalam, Edisi III, Jilid II. Jakarta: Balai Penerbit FKUI

Shima, R, Farizah, M,H, Majid, H,A. (2014). A qualitative study on hypertensive care behavior in primary health care settings in Malaysia. Scientific and medical research. Volume 8 : 1597-1609

WHO (2013). A global brief on hypertension: silent killer, global public health crisis

WHO (2012). The Pursuit of Responsible Use of Medicines: Sharing and Learning from Country Experiences. Geneva:

http://www.who.int/medicines/publica tions/responsible_use/en/index.html 
NERS: Jurnal Keperawatan, Volume 14, No. 1, Maret 2018, (Hal. 1-10)

Yupan, Wenpeng, Qi chen, \& Wei Dong (2015). Association between anxiety and hypertension: a systematic review and meta-analysis of epidemiological studies, Neuropsychiatric Disease and Treatment, Vol 11: 1121-1130 